\title{
Decolonizing the Study of Religions: Muslim Intellectuals and the Enlightenment Project of Religious Studies
}

\author{
Abdulkader Tayob \\ Abdulkader.Tayob@uct.ac.za
}

\begin{abstract}
The term 'religion' as a discursive term occupies a dominant, but neglected feature of Muslim intellectual reflections since the $19^{\text {th }}$ century. Intellectuals from Muhammad 'Abduh (he died in 1905) to recent scholars like Nașr Ḥāmid Abū Zayd (he died in 2010) have used religion as a critical term to develop a critique of tradition and modernity, and a strategy for renewal. This discourse may be compared with the study of religion since the $19^{\text {th }}$ century that has also used religion to develop a perspective on the religious history of humankind. In this contribution, I argue that the two intellectual traditions that have employed religion - Kantian and the modern Islamic - point to very different ways of relating to the world, to the self and the 'other', and to the political condition of modernity. Rather than using the hegemonic Western tradition to make a judgment on the modern Islamic, I use the latter to point to the former's peculiar proclivities. Using the modern tradition among Muslim intellectuals, I invite an inquiry into both from each other's positions.
\end{abstract}

Keywords: Islamic studies, Islamic modernism, Islamic reform, religious studies, religion, Talal Asad, postcolonial, decolonial 


\section{Abdulkader Tayob}

\section{Introduction}

Universities in South Africa and elsewhere have been called to revisit the colonial and imperial foundations of their disciplines and methods. Adopting the term 'decolonial' as opposed to 'colonial' and 'postcolonial', students and scholars have demanded that universities detach themselves from the assumptions, practices, and values of Western scholarship (Grosfoguel 2011; Nakata, Nakata, Keech \& Bolt 2012; Mignolo 2007). The contribution of postcolonial scholarship from the likes of Edward Said, Giyatri Spivak, Partha Chatterjee, and many others has been recognized and sometimes applauded its critical rejoinder to the colonial roots of the social sciences and humanities. However, it also stands accused for not completely overturning the colonial epistemological framework. Generally, the postcolonials are accused of using Western norms and terms to deconstruct dominant narratives. Foucault, Derrida, and Gramsci stand central in these critical reflections (Grosfoguel 2011; Mignolo 2007). In spite of themselves, they remain trapped - more or less - in the West's hegemonic intellectual universe.

This blanket condemnation cannot be sustained, and a closer look at the longer history of anti-colonial intellectual movements may offer unexpected insights. Studies on these earlier traditions need not focus on the dominant colonial narrative that always hovers in the foreground, but at the intellectual gestures of resistance and construction that traced a different intellectual history from the West. Assigning all previous anti-colonial traditions to the domain of the colonizer erases the contribution and value of the colonized and the subjugated. Such neglect reaffirms and confirms a deep colonial habit that the colonized may not speak as Spivak reminds us in her seminal essay (Spivak 2006). It assumes that scholars on the periphery of the colonial and postcolonial worlds were only reproducing the dominant tropes of the center. Taking seriously previous acts of resistance, intellectual or otherwise, brings the colonized and subjugated to the center of this decolonial moment.

In this contribution, I revisit the religious tradition of reform (tajdid) or awakening (nahdah) that was launched in the $19^{\text {th }}$ century in various Muslim societies across the globe. I argue that it turned into a sustained intellectual project to rebuild and create a new intellectual discourse of Islam between the past and the present. The focus of this essay rests on religious discourse, arguing that it was a creative construction of tajdìd (renewal, reform) with a 
redefinition of religion and its linguistic referents. Using case studies from Muḥammad 'Abduh and Nașr Ḥāmid Abū Zayd, I argue that this intellectual reconstruction was founded on a discourse of religion $(d \bar{i} n)$. Such a discourse probed into the essence of religion and its functions, its meaning, its location in public and private life, and sometimes its distinction from the secular. The Islamic reformist discourse was an attempt to rethink the origin, meaning, functions, and language of religion for Islam and Muslims. Moreover, its intellectual and political interests may be usefully compared and highlighted with its Western counterpart that was emerging simultaneously in Europe, and that has since become known as religious studies, the history of religions, comparative religions, or sometimes the science of religion.

\section{Religious studies in postmodern postcolonial perspectives}

In order to consider this religious renewal as an intellectual discourse, I want to turn to the discourse of religious studies which, since the last quarter of the $20^{\text {th }}$ century, has been the focus of critical scholarship. Like other disciplines of the humanities and the social sciences, the study of religions has undergone a postmodern and a postcolonial critique of its origins, methods, and purposes. Some have focused on the theological proclivities that lurk in the study of religions, while others have pointed to its imperial and colonial collusion. These critical perspectives have built on Michel Foucault's deconstruction of the modernist project ${ }^{1}$. They have unsettled the foundations of the discipline of religious studies, by turning it into an object of analysis. Where previously the 'science' of religious studies would be used to study a religious movement such as Islamic modernism, it can now occupy a position alongside it as a discourse that is subject to similar scrutiny and analysis.

Jonathan Smith stands out as an early critic of the discipline. Some of his earlier remarks question the ontology of the sacred and the profane assumed in the discipline. While scholars of religion were assuming that the sacred and profane existed in the world inhabited by religious traditions, Smith argued that both were created through religious beliefs, texts, and practices (Smith

1 Using a genealogical approach that he developed from Nietzsche, Foucault pointed to the unthought and unexpected outcomes of what started off as rational and objective quests to understand the human condition (Foucault 1977). 


\section{Abdulkader Tayob}

1978:97). While Eliade was discovering the mechanics of the sacred and profane, Smith was pointing to their creation through practices. Ritual, for example, was not a way to encounter an existing sacred, but it

represents the creation of a controlled environment where the variables... of ordinary life may be displaced precisely because they are felt to be so overwhelmingly present and powerful. Ritual is a means of performing the way things ought to be in conscious tension to the way things are in such a way that this ritualized perfection is recollected in the ordinary, uncontrolled, course of things (Smith 1980:63).

Ritual was creating a classification of what is and what ought to be. For Smith, on the contrary, 'there is nothing that is inherently sacred or profane. These are not substantive categories, but rather situational or relational categories, mobile boundaries which shift according to the map being employed. There is nothing that is sacred in itself, only things sacred in relation' (Smith 1982:55).

Smith uses a Saussurian or postmodernist framework to point to the arbitrary connection between the signifier (ritual, religion, etc.) and its signification (the sacred). These signifiers were social and cultural processes and productions. From this awareness that religions were creatively engaged in this ordering. It was a short step to reconsidering the role played by religion in the study of religions. Smith argued that the category 'religion' was invented to provide a useful service. The study of religions was engaged in a discursive construction of a category:

'Religion' is not a native term; it is a term created by scholars for their intellectual purposes and therefore is theirs to define. It is a secondorder, generic concept that plays the same role in establishing a disciplinary horizon that a concept such as 'language' plays in linguistics or 'culture' plays in anthropology (Smith 1998:269).

There was no platonic-like 'idea' called 'religion', but a category imagined, created, and utilized by scholars of religions to identify and interpret phenomena. There was no underlying reality called 'religion' with a structure, function, and essence waiting to be discovered. The assumption that such a term refers to a reality, vague or idealized, is misguided. This critique was a 
deconstructive assault on the project of religious studies that aim to represent religions in particular, and religion in general.

According to Capps, the seeds of this modernist framework were sown by Immanuel Kant when he proposed an a priori distinction between natural and revealed religions. Revealed religion was the religion represented in the Bible and other similar world religions, while natural religion was the idealized religion rooted in morality. Historical religions more or less reflected this idealized Kantian noumenon (Capps 1995:7). In the $19^{\text {th }}$ century, the study of religions came to maturity when liberal Protestant theologians and their detractors used this Kantian framework to study religions in history and society. Those more committed to Christianity found their own religion to match the noumenon of natural religion that Kant posited. The natural religion of Kant became an idealized Christianity or an idealized religion. This trend reached its high point with Mircea Eliade in the 20 ${ }^{\text {th }}$ century (Capps 1995:117146).

Those who were not inclined to theology, approached religion with a different set of questions. They followed functionalist questions on the effect of religions, its distinctive language, or its implications in politics and economics (Capps 1995:158, 209), but they always searched for recurring patterns and styles that characterize rituals, myths, and beliefs. Whether it was the ideal types of Weber or the styles of aesthetics more recently dominating the discipline, an underlying conception of religion (noumenon) with distinctive patterns and styles was not too far from the surface. The Kantian idea of the noumenon was becoming increasingly difficult to identify, but it remained in the background. It is not by accident that the Journal of the International Association for the Study of Religions, founded in 1954, is called Numen, meaning 'a spiritual force or influence often identified with a natural object, phenomenon, or place' (Merriam-Webster Dictionary 2018). The journal name belies the deep assumption of the discipline. In a slightly different critique of this history, Murphy argues that the study of religion was tracking the Hegelian fulfilment of the spirit (Murphy 2014:\#9584). Whether the study of religion can be traced to Kant as Capps suggested, or Hegel, the argument of Jonathan Smith that religion as a general category or concept was assumed and invented for the discipline, is clear. Smith's criticism is a reminder of this ghost of Kant and Hegel in the work of $19^{\text {th }}$ - and $20^{\text {th }}$-century scholars of religion. 
Like other modernist inventions, religion belongs to the fertile imagination of modernist scholars, but in the case of the study of religions, the spirit of this critical mood in the discipline has been particularly directed against the theological proclivities that lurk in the discipline. The critical reflections of Smith were used to unmask this theology, without always recognizing its modernist Kantian or Hegelian roots. In some of the scholarship, old and new theologies became the target, and the Western modernist invention of religion deflected from direct criticism. Donald Wiebe and Russel McCutcheon stand out in this line of inquiry. Wiebe focuses his attention on the theology that undermines the discipline of the study of religion - from some of its eminent founders to current leaders (Wiebe 1991; 1994a; 1994b). He sometimes waxes nostalgic that the earliest founders of the discipline had been overturned by closet theologians who undermine the scientific basis of the discipline. McCutcheon follows a similar line of argument, focusing his energy on the fact that such a theology finds its way into the discipline by emphasizing that religion is unique (sui generis) and cannot be explained by other social facts and developments (McCutcheon 1995:302; 1997). Neither of these scholars considers the postmodernist criticism of positivism and modernity, nor do they seriously question the location and dominance of the discipline in Western, secular countries. In a rare admission that the terms used in religions originate in the West and from Christianity, McCutcheon brushed aside this important point (McCutcheon 1995:300). Committed to explanatory frameworks for the human and social sciences, Wiebe and McCutcheon belie a teleology that Western and nonWestern scholars will eventually reach emancipation and enlightenment.

This anti-theological spirit merits critical reflection for its discursive place in religious studies. The study of religion maintains a special relationship with theology, particularly Christian theology. The discipline emerged in Europe within theological faculties, from which it has tried in vain to distance itself. The theological shadow runs quite deep and may even be lurking in the critical scholarship that regularly announces its opposition to it. Apart from Wiebe and McCutcheon who maintain the boundaries of the discipline against theological incursions, we may compare Jonathan Smith's argument that religion is not a native category with a similar argument first made by Wilfred Smith in the study of religion twenty years earlier, and whose Christian theological preoccupations are well known. Wilfred Smith argues in his influential The meaning and end of religion that religion as a reified object of 
study should be discarded in favor of religiosity (Smith 1962). Like Jonathan Smith, he too argues that religion was an invention of the study of religion, but he argues on theological grounds that the term prevented scholars from grasping the deep experience of religious people. For Wilfred Smith, religiosity was real and worthy of scholarly attention. He was not taking a postmodernist approach, but a theological one indebted to Paul Tillich and eventually to Kant and Protestantism (cf. Capps 1995:289). The essence of religion lay not in a tradition, but a feeling or experience. Jonathan Smith also rejects its reality but argues that it was an invention useful for scholars of religion. The close affinity between a Protestant theologian and a critique may not be as coincidental as it sounds.

The postmodernist and theological Smiths may be distinguished from postcolonial scholars who have also recognized the invention of religion as an analytical category but went further by showing how the category was native to the history of the West. Talal Asad has taken the lead in this direction. Following the genealogy of religion, he shows how religion as a practice and category was transformed over a period of time in the church, in Western judicial thinking, and in the academic study of religions (Asad 1993). In a later book, he turns attention to the discursive construction of the secular. Here he shows how the idea of religion in the discourse of the modern state is vital to the construction of a secular framework and ethos. Religion and the secular are co-created in the modern academy and the modern state: 'Religion has been part of the restructuration of practical times and spaces, a re-articulation of practical knowledges and powers, of subjective behaviors, sensibilities, needs, and expectations in modernity' (Asad 2001b:221).

Asad points to the discursive power of religion in Western societies, and unlike the Smiths and others, he turns his attention to the role played by the discipline in the history of Europe. Asad's critical insight on the modern state's politics of religion-making has been shown in other colonial and postcolonial encounters (Dressler \& Mandair 2011; Dubuisson \& Sayers 2003; King 1999) ${ }^{2}$.

2 A similar, but not postcolonial approach is evident in the work of Hans Kippenberg who has shown how religion, constituted in the study of religion as a category, was part of broader political and intellectual movements in Europe (Kippenberg 1983; 2000; 1994). 
At the University of Cape Town, David Chidester went beyond the academy and the history of the West. In a series of books, he has shown how religion as a term was reproduced in the structures set up by the modern and postcolonial modern state. He shows how such definitions were used on the colonial and imperial frontiers. The theories formulated by scholars to understand religions were applied in projects of subjugation and extermination. The systems of classification of the self and the 'other' were not neutral signifiers, but applied with violence and brutality in colonial wars of conquest and domination (Chidester 2004; 1996; 2014). Religion as a term may have been invented by scholars, but it was not completely dislocated from the political, religious, and social histories in which scholars operated.

This brief review shows that the study of religions has a history in the Enlightenment project, with a particular focus on renewing or inventing a Christian liberal and Protestant theology. A more secular approach to the study of religions that focuses attention on patterns and contours of the religious has not strayed too far from its Kantian and Hegelian roots (exceptions include Murphy 2014; Raschke 2012). There has been an equally persistent entanglement with Christian theology that must be excised, making this feature a part of the discipline. Moreover, the discipline thrived on the representation of the 'other' that merged with national and colonial interests. All these were part of an allegedly neutral, or what Strenski as late as 2015 calls in his revised textbook, a 'curiosity' about religion, its elements, and its effects (Strenski 2015:171). Postmodern and postcolonial scholarship has unmasked this curiosity.

With this background, it becomes difficult to uncritically use the terms and methods of the discipline without a great deal of circumspection. In an essay titled Beyond religious studies?, Chidester suggests a Hegelian stance of Aufhebung, 'cancelling and keeping, disposing and transposing' (Chidester 2017:75). Rather than holding on the coattails of this and other German and Western ancestors, I suggest that we start looking at the study of religions as an intellectual discourse in other cultural, historical, and political contexts. We should turn more seriously to the study of religion from the vantage point of the colonized, rather than restrict ourselves to merely reforming and refining the dominant discourse in order to continue objectifying religious movements and phenomena elsewhere. In this essay, I begin with the discursive tradition launched by Muslim intellectuals and how they construct a discipline of religion with very different goals and effects. 


\section{What is Islamic modernism or Islamic reform?}

Before the rise of fundamentalism and radicalism, the scholarly gaze was very much locked on to the development of what was generally called Islamic modernism. There are some insightful sociological studies conducted on its rise and its emergence among new social groups produced by colonialism and capitalism. These include the work of Schulze, Abaza, Moaddel, and Weissman who follow a classic Weberian approach that matches religious developments to new social groups (Weismann 2001; Schulze 2000; Moaddel 2001; Moaddel \& Talattof 2000). My interest lies in the ideas produced in Islamic modernism, and their contribution to an intellectual discourse of Islam. Islamic modernism as an intellectual movement has not been given much credit. As Masud and Salvatore concludes, Western scholarship for the most part turned 'around the key theme of Islam's inherent deficit in coping with...modernity' (Masud \& Salvatore 2009:50). However, since the 1980s, the work of Talal Asad has opened a space to consider the discursive nature of religion in general, and Islamic in particular. Applying a discursive approach to Muslim intellectual labor, though, has not been uniform. Asad and those who followed him closely have used the idea of a discursive tradition to highlight the difference between an Islamic discourse and a western secular discourse of modernity. A strong binary logic informs their work, with an unfortunate judgment that Islamic modernism does not belong to a Muslim discourse. There are also others who have used Asad's insights to point to transformations in the Muslim discourse and have been thus more accommodating to Islamic modernism. There is a distinct difference in the two readings, their identification, and representation of a modern Islamic intellectual discourse.

Mahmood and Hirschkind have marked what may be called a dominant reading of Asad which casts Islamic modernism as a Western cultural and imperial invasion. In their influential studies on piety movements, they have represented Islamic discourses as the antithesis of Western discourses of the self and ethics respectively (Hirschkind 2006; Mahmood 2005). Mahmood argues that the women's mosque movement in Egypt cannot be studied through the assumptions of a Kantian framework of freedom and agency. Using the idea of an embodied ethical tradition, she shows how piety was cultivated and developed without the need or necessity of freedom, agency, and choice. She particularly rejects the idea of reading resistance in 


\section{Abdulkader Tayob}

women's religious practices as many feminists have argued (Mahmood 2005:23; El Guindi 1981; Macleod 1991). Hirschkind follows a similar method in identifying ethical practices through listening to and engaging with popular sermons through cassettes and radio broadcasts. He also identifies an ethical discourse of engaging, listening, and correcting the self. While some level of agency is admitted in the discourse identified by Hirschkind, he too concludes that the movement was not 'simply a modernizing turn toward an increasingly individualized form of rational piety or as the deployment of religion for the task of consolidating a national culture' (Hirschkind 2001:4). He believes that the discourse 'need[s] to be analyzed in terms of a particular articulation of personal and political virtue within contemporary Islamic discourse' (Hirschkind 2001:4). Clearly, Mahmood and Hirschkind are privileging insider (emic) terms to represent a unique non-Western Islamic discourse.

More can be said of Mahmood and Hirschkind's representation of Islamic discourse, but I find it more important to focus on their representation of Islamic modernism. In a highly cited work, Mahmood describes the Islamic modernism of Abū Zayd and his teacher Hasan Hanafĩ as nothing but an echo of imperial American hegemony (Mahmood 2006:337). Much earlier, Hirschkind also attempted an analysis of Abū Zayd's work in comparison with his Islamist adversaries in a telling title Hermeneutics or heresy. Using the Islamic discourse of his detractors as a yardstick, Hirschkind concludes that Abū Zayd's ideas are the product of a Western intellectual hegemony (Hirschkind 1995). One may find echoes of this judgment of so-called Muslim modernists in some of the essays written by Asad on modern Islamic discourses. In his path-breaking book, Genealogies of religion: Discipline and reasons of power in Christianity and Islam, Asad discusses the criticisms directed at the Saudi government when it invited American troops to defend the Kingdom during the 1992 Gulf war. He singles out young religious scholars ( 'ulama ') who used the discourse of nașiha to direct a 'morally corrective criticism' at the king (Asad 1993:214). As sound advice, nașinha was part of the 'Islamic tradition' and the 'ground on which that reasoning takes place' (Asad 1993:236). He also mentions what he calls Western-educated moderns who opposed the state but expressed their concern in private or directly to some of the princes. Asad, however, adds that 'they do not characterize their criticism in terms of the Islamic concept of nașinhah' (Asad 1993:222 note 45). $\mathrm{He}$ seems to include only religious scholars as participants in an Islamic discourse, and ignores the historical role played by non-religious intellectuals 
such as poets, writers, mystics, and philosophers who acted as advisors to Caliphs, Sultans, and military leaders. In another essay on the transformation of the Sharīah in Egyptian law courts, Asad discusses the role of Islamic modernists like Muhammad 'Abduh and Ahmad Safwat in this reformulation. I will discuss 'Abduh below. Asad identifies Safwat as 'a British-trained lawyer and advocate of sharia reform, who, like other evolutionary Victorian thinkers, saw the Qur'an as an archaic religious text that mixed together moral and legal rules, rules whose real significance must be identified by a historical teleology' (Asad 2001a:10). This characterization of Safwat places him outside an Islamic discourse as demarcated by Asad. 'Abduh, in Asad's view, was not completely secularized due to his earlier exposure to Sufism. In general, though, Asad recognizes the contribution of modernist Muslims only in their support of and participation in 'secular politics'. This representation of Islamic discourse reserves the right of judgment on the authenticity of Islamic modernist ideas, in favor of Islamist and piety discourses that maintained a theological framework that seemed to match the past and oppose the West. In spite of Asad's explicit caution that voices of dissent should not be avoided in the study of Islam, he and his readers have done exactly that (Asad 1986:16).

One can read Asad different from himself, taking a significant cue from his seminal essay: 'An anthropology of Islam will therefore seek to understand the historical conditions that enable the production and maintenance of specific discursive traditions, or their transformation - and the efforts of practitioners to achieve coherence' (Asad 1986:17; emphasis added). Also citing Asad, Armando Salvatore argues that a modern Islamic project, which includes both modernists and Islamists, was produced in conversation with Western interlocutors. He argues for an Islamic modernity that parallels and intersects with European modernity (Salvatore 1997). In numerous publications, John Bowen has found inspiration in Talal Asad for his study of Muslim discourses in local contexts (Indonesia and France) and in their encounter with modernity (Bowen 1987; 1989; 1993; 2001; 2004). Working on the reformist projects of the $18^{\text {th }}$-century Muhammad Ibn 'Abd al-Wahhāb and the $19^{\text {th }} / 20^{\text {th }}$-century Muhammad 'Abduh, Samira Hajj also follows Asad and shows the transformation of an Islamic discourse of revival and reform (Haj 2009). She shows that 'Abduh, in contrast to Ibn 'Abd al-Wahhāb, sets up the framework for an Islamic modernity that remains committed to its historical discursive framework. In her study of more conservative trends in Egypt at the end of the $20^{\text {th }}$ century, Salwa Ismail pays close attention to an 


\section{Abdulkader Tayob}

Islamic discourse informed by political and class interests (Salwa 2003). All these studies have not excluded modernist contributions to a Muslim discourse of religion that is open to change.

The impact of Asad has been influential in introducing a postcolonial critique in the study of Islam. It offers a window of opportunity to approach Islamic modernism, not as an object of study, but a discursive tradition in its own right. There is, however, a divergence in reading Asad, between those who value the role of Islamic modernists in an Islamic discourse, and those who see them as alien interlopers who have rejected the foundation and essence of the discourse. Asad himself and those who follow him closely represent Islamic discourse as the antithesis of a Western discourse of modernity, but there are scholars who appreciate the longer history of Islam, and try to identify Islamic modernity as a style of reasoning or response that is embedded in the history of Islam (cf. Voll 1983; 1982; Hoebink 1998). They also pay close attention to the transformation in the Muslim discourse.

\section{Islamic modernism as an intellectual discourse}

I propose that we go beyond the metaphor of an encounter to appreciate the intellectual labor of modernist Muslims. Islamic modernism is not simply an uncritical or unconscious adoption of some modern, Western ideas that brushed off on those who read a book, studied in the West or met some Western intellectuals. They are reflexively and consciously creating definitions and categories of religion and the religious that are then applied to Islam and Muslims in the past and the present. They are doing what social scientists think is their exclusive preserve.

Like other postcolonials, Asad questions the validity of using standard tropes and theories developed in the study of Islam in anthropology:

[O]ne's conception of religion determines the kinds of questions one thinks are askable and worth asking. But far too few would-be anthropologists of Islam pay this matter serious attention. Instead, they often draw indiscriminately on ideas from the writings of the great sociologists (e.g., Marx, Weber, Durkheim) in order to describe forms of Islam, and the result is not always consistent (Asad 1986:12). 
Later in his essay he makes a more emphatic point when writing on how argument is written out in the study of an Islamic tradition:

In their representation of 'Islamic tradition', Orientalists and anthropologists have often marginalized the place of argument and reasoning surrounding traditional practices. Argument is generally represented as a symptom of 'the tradition in crisis'... But these contrasts and equations are themselves the work of a historical motivation, manifest in Edmund Burke's ideological opposition between 'tradition' and 'reason', an opposition which was elaborated by the conservative theorists who followed him, and introduced into sociology by Weber (Asad 1986:16).

Asad asks scholars of Islam and religions in general to be self-critical of the terms used from Christianity and the history of the West. These terms have a particular history which should not be uncritically applied to other cultures and traditions. He asks anthropologists, particularly scholars based in Western academies, to be conscious of the definitions of religion that they assume, and then use to posit representations. Asad introduces himself to anthropologists and social scientists in general, asking them to be more vigilant in their appraisals and representation. In an extensive review of critical scholarship that addresses the Western provenance of the terms in the study of religions, McCutcheon acknowledges this problem raised by Asad and Ninian Smart. Like most critical scholars, McCutcheon is unable to stray beyond the Western academy (McCutcheon 1995:290, 300).

The fact is that Muslim modernists since the $19^{\text {th }}$ century have created and defined terms to analyze, classify, and make judgments. It happens that they have used the very term used in the Western academic study of religions. Many a scholar of Islam, who is self-consciously adopting a definition of religion as Asad advises, would come across many a Muslim intellectual doing the same. They will find that they have used religion to launch and develop a discipline of Islamic modernism, or what I would prefer to call, Islamic reform. Recognizing this intellectual labor suggests that we appreciate a discourse of religion among Muslim reformists who are usually only studied as objects for analysis. Rather than merely identifying Islamic modernists as imperfect moderns, hybrids between Islam and the West, or heretics, I turn to them as developers and participants of a discourse on religion. 
Apart from scholars like Salvatore (1997) and Carool Kersten (2011), most studies on Islam ignore the self-reflexive and critical work done by Muslim intellectuals. A discourse of Islamic reform, led by reflections and inventions of religion and the religious as discursive constructions, helps their creators to produce new political and religious subjects, critique existing traditions, and chart new futures. It is a discourse that draws on the ideas of religion and reform that predates modernity. The word for religion and its plural exists in the intellectual history of Islam, and is extensively discussed in premodern theological, philosophical, and mystical works. From the $19^{\text {th }}$ century, however, it is redefined and rethought, and plays a constitutive role in discussions and debates among Muslim scholars and intellectuals.

\section{Modern Islamic reform: A discourse on religion}

I would like to present two contributors to this intellectual discourse. The first one comes from the $19^{\text {th }}$ century in the exchange between Jamāl al-Dīn alAfghānī and Muhammad 'Abduh on the one side, and Ernest Renan and a French Foreign Minister, Gabriel Hanotaux, on the other. Al-Afghānī and 'Abduh are considered to be the founders of an Arab Islamic reformism and their impact and influence spread far into the $20^{\text {th }}$ century. Focusing only on 'Abduh's writings in this exchange, I will show how he employs religion as a discursive term to identify Islam, criticize colonial practices, and imagine a different future for Egyptians and Muslims. My second example comes from the work of Nașr Abu Zayd, where I will show how he uses the category of religion to criticize religious discourse and to fashion a new way of reading the Qur'an.

Born in a peasant family in Lower Egypt in 1849, 'Abduh was already looking for something better than the traditional education he was exposed to in Tanta. An uncle directed him to Sufism and then to the emerging modern sciences. Al-Afghānī's visit to Egypt in 1872 had a profound personal and intellectual effect on him. In his first book written in 1874, Risālat al-Wāridāt, 'Abduh describes al-Afghānī as his spiritual mentor. He completed his studies at Azhar, and took a teaching position for a short while. He was soon embroiled in the political upheavals of the day. Suspected of involvement in the anticolonial revolt of Ahmad 'Urabi Pasha (1879-1882), he was banished from 
Egypt. He spent a short time in Paris with al-Afghānī where they formed an organization called al- 'Urwat al-wuthqā and published a newspaper under the same name. The organization and newspaper did not last very long, and 'Abduh soon headed to Beirut to continue a career more directly engaged in teaching and law. He gave a series of lectures on theology which were later published as Risālat al-tawhìd (The epistle of the unity of God - 'Abduh 1368). In 1889, 'Abduh was allowed to return to Cairo, and given a number of important juridical and teaching posts. His reformism and moderation seemed to have been appreciated by the Khedive of Egypt and his British overseers. Until his death in 1905, 'Abduh devoted himself to the reform of education, religion, and law. It seems that he reconciled himself to colonial power, but still maintained to oppose foreign rule. In 1897, the well-known Damascene scholar and admirer of 'Abduh and al-Afghānī, Muḥammad Rashīd Rị̣ā, arrived in Cairo in order to begin a journal for reformist Islamic thought. The journal, al-Manār, began publishing in 1898 and continued until 1940. The articles in the first issues were mainly written by 'Abduh. His various writings have established an intellectual foundation for Islamic reform.

'Abduh defines religion as an innate, human quality that is difficult to erase from the human constitution and from human experience: 'Dinn (religion) is a divine imprint ( $w a d^{\prime}$ 'ilāhi $)$, its distinguishing mark and motivation for humanity' ('Abduh 1989:15).

It is as if the human being, when he was a pure slate, the first to draw on him was religion, which then affected his deeds... It rarely happens that one rejecting his religion can ever escape its effects - it remains with him like the mark of a wound on the skin after it has been healed ('Abduh 1989:15).

Religion is both innate and experiential. It is given by God but experienced by humans in a deeply profound way. The negative and long-lasting impact of religion is noteworthy in 'Abduh's characterization. He adds two other aspects of religion that seems to come directly from Islamic theology: 'Rational minds learn it from the prophets, and so it is acquired thus by those who do not receive revelation' ('Abduh 1989:15); and the 'sending (mission) of Prophets... is one of the perfections (mutammimāt) of human existence and among (the) important needs for his subsistence' ('Abduh 1368:10794). 


\section{Abdulkader Tayob}

Reason and prophets play an important role in the formation and perpetuation of religion. For 'Abduh, they confirm the value of religion.

The foundations of religion in creation, experience, prophecy, and reason could not be dissociated from its social value. Reason and religion, when they go together, produce progress:

Religion is that through which reason expands knowledge, and spreads over the world; and reaches the higher skies; (it aids reason) to ponder the signs of God, and to discover the secrets of his creation; or to derive his laws. All the sciences are pastures for minds to reap from them what they desire, and to reach pleasure to the extent that they like. But when religion stops, and absolute certainty takes over, then knowledge stops and its wind dies down. And this does not happen all at once, but follows the logic of history ('Abduh 1989:160).

Religion supports reason and development, but religion without reason leads to retrogression. Religion may also lead to chaos and destruction when abused for political ends, as it happened in the history of Islam, but 'Abduh did not miss the abuse of religion in colonial projects:

I have mentioned religion among the elements of power because Mr. Hanotaux does not deny that Europe depends on religion for the politics of colonization. That the missionaries and religious associations are among the most important tools it has to prepare people to accept its authority when it suits them, and to prepare them to tolerate the power that bears upon them and envelopes them ('Abduh 1989:86).

Religion, reason, and social value are not too far from each other in 'Abduh's reflections. He develops this relationship between religion and progress more clearly in his opposition to a thesis promoted by Ernest Renan. Renan argues that Aryan religion promotes progress and civilization while Semitic civilizations and religions do the opposite. In response, 'Abduh considers Aryan religion to be the root cause of the decline of society. He argues that religion as articulated in Semitic civilization was conducive to progress and development. 'Abduh lies the blame for the decline of Muslims on non-Arabs and non-Semites for steering its simple Semitic roots towards an Aryan 
religion, but he is not always consistent, as he also produces counter-examples in the history of Buddhists (Aryan) and the Phoenicians (Semites) that contradict the value of this line of reasoning ('Abduh 1989:69). He is perhaps aware that the simple one-on-one relation between a religion and progress is difficult to prove conclusively.

This is a very short summary of 'Abduh's ideas, but sufficient to show how he uses the idea of religion to think about the malaise of Muslim societies, the power of religion to effect change, and the complexities of such an approach. The discourse of religion in 'Abduh creates a vision of the past, the present, and possible future. He thinks about Islam through the concept and definition of religion. This value of Islam as a social good became very common among large groups of Muslims in the $20^{\text {th }}$ century.

I now turn to Nașr Abū Zayd who flourished one hundred years after 'Abduh. Abū Zayd began writing on the Qur'an, commentary, and linguistics in the 1980s, and continued unabated until he passed away in 2010. He catapulted into the public sphere when his promotion to professorship was contested at Cairo University in 1993. When this attempt to block his promotion failed, his opponents approached the Egyptian courts to annul his marriage on the grounds that his work constituted apostacy. As that was a time when outspoken thinkers were targeted by assassins, Abū Zayd was forced into exile. He was critical of both the government and the religious groups in Egypt, which he presented in numerous articles, public lectures, and essays. He lived the next period of productive life in the Netherlands but was always engaged with scholars throughout the Muslim world (Abū Zayd 2001).

There are two outstanding themes in Abū Zayd's work, and religion stands out in both of them. He approaches the study of Islam through the linguistic and discursive trends that dominated the social sciences in the 1980s. I have found neither Asad nor Foucault in his work, but rather Ferdinand de Saussure (he died in 1913) on his theory of language. Abu Zayd embraces the distinction between the langue and parole in the working of a language - the first referring to the structure of a language and the second to its usage. The first theme in his work lies in identifying the discourse (langue) of the Qur'an - the semantic system that makes possible meaning of the text in its particular context. He calls this discourse of the first foundational texts of Islam its dinn. His second theme lies in the identification of the parole of the Qur'an in history. Din refers to a set of texts that appeared in history, and the Qur'an is its most prominent representative (Abū Zayd 1994:197). According to him, the 


\section{Abdulkader Tayob}

Qur'an is a discourse to be read in the context and language of its time. He argues that not only is its meaning framed by Arab culture, but also by the experiences of the Prophet Muhammad:

The Qur'an as a mode of communication between God and man teaches us something more beyond 'law' and 'politics' in the narrow sense of the two terms. It teaches us that the literal interpretation means that we lock the Word of God in the moment of its historical annunciation. Put differently, we are taught to limit the meaning of the Qur'an to the first phase of its historical construction (Abū Zayd 2000:15).

Abū Zayd does not hereby argue that the Qur'an offers no fundamental values for its readers, or that the text is open to any reading. As an illustration of this subtle point, we may turn to an essay that he has written on justice in the Qur'an. He recognizes the particular meaning of justice in many verses but turns the attention to what he calls the 'foundations' of religion rooted in the covenant between God and humanity and in the innate nature of the human constitution (fitrah). He argues that justice, which for him means a careful and delicate balance, is central to the message of the Qur'an. It is, in other words, an essential meaning. Through the discourse of the Qur'an, human beings are reminded of this value. But the form in which justice takes shape in society, changes. A reading of the Qur'an in context therefore leads to a value and an appreciation of its contextual application. Justice as a value emerges in the discourse of $\operatorname{din}$ (Abū Zayd 2001).

Is there a set of eternal values in the Qur'an? Sometimes it appears that this is so in Abū Zayd's research, but he is aware of this problem in light of the hermeneutical framework he has adopted for his work. He does not forget the ideology at work in the reading of a book, including his own reading of the Qur' an (Abū Zayd 1988). In a comparative study of Qasim Amin and Tahir alHaddad, Abū Zayd categorically rejects this possibility: '[T]he essence of Islam is not an immutable given but is one that is constantly subject to inference and to rediscovery in tandem with the growth and development of human consciousness' (Abū Zayd 1999:219).

One should therefore search for values, but they are not immutable and permanent, they are revealed in the act of reading. On this particular value of justice, Abū Zayd has also developed an argument first made by the Pakistani 
intellectual, Fazlur Rahman. For the latter, Qur'anic values are immutable while the contexts change (Rahman 1979:39). As Abū Zayd is suggesting that the deeper values themselves may change, he is treading a fine balance between a deep meaning and the effect that readers have on that change. Taking these statements all together, I am showing a discursive strategy in Abū Zayd working with religion and its values and essence, on questions of contexts, permanence, and change.

For the second theme in his work, Abū Zayd makes a distinction between the values that he reads in the Qur'an in its first 'annunciation', and a critical stand that he expects from contemporary readers. The gist of his second theme is captured in the following statement:

(While) we are taught to limit the meaning of the Qur'an to the first phase of its historical construction... we have to be aware of the other phase(s) in order to grasp the dynamics, according to which the Qur'an has been able to form and shape the life of Muslims. Awareness of the essential characteristic of the religious language in general could protect us from being totally immersed in its indoctrinated atmosphere and thus lose our human identity (Abū Zayd 2000:15).

Abu Zayd recognizes the historicity of reading the Qur'an for its first generation, and the readings that were multiplied in later centuries. He expects a scholar to be aware of the differences in these interpretations and readings. In order to show this, he devotes considerable space to identifying and criticizing these various religious readings (al-fikr al-dīn $\bar{\imath}$ or al-khițāb al-dīn $\bar{\imath}$ ). Following De Saussure, they are the parole of the Qur'an in history and in contemporary societies. He began his career with some insightful work on the hermeneutics of classical Islamic scholars and intellectuals like Hasan al-Basri, al-Shafi' '̄i, al-Ghazzali, and Qāḍ̄ Abd al-Jabbār (Abū Zayd 1993; 1996a; 1996b). He showed how their ideological readings changed or subverted the meanings of the Qur'an for political and theological ends. Abū Zayd also showed the ideology and theology of Arabic grammar on which premodern scholars founded their varied disciplines (Abū Zayd 1988). After the early 1990s, when he was attacked by fellow citizens, he became more concerned of what he saw was the danger of religious politics in Egypt and in other Islamic countries. Thenceforth, he focused his attention on a new modern 'religious thinking' and outlined its key characteristics. He identified religious discourse 


\section{Abdulkader Tayob}

as one which refuses or hides human agency in the reading of a text, reduces or conceals causality in favor of the absolute agency of God, and uses terms to collapse the distinction between different periods of history (Abū Zayd 1994:81). He argues that this religious thinking, this new parole, pervades contemporary Muslim religious trends (Abū Zayd 1994:94).

Like 'Abduh, Abū Zayd employs the concepts of religion and the religious to develop a method of reading the Qur'an and contemporary challenges facing Muslims. He identifies $\operatorname{din}$ (religion) as a discourse that demands to be read with great care and circumspection, particularly with regard to its first enunciation. Reading the Qur'an in context does not mean abandoning its deep values. Focusing on its first 'annunciation' in context provides a basis for understanding its original meaning, but subsequent readings are open to misreadings that a reader must not forget. He identifies 'religious thought' (al-fikr al-dīn $\bar{\imath}$ ) as ideological readings that call for a great deal of critical evaluation.

\section{Concluding remarks: Islamic reform (Tajdīd) as discourse}

I have presented two examples of Islamic modernism that point to a discourse of religion employed to develop a critique and a vision for the transformation of society. Across time and geography, Muslim scholars in the modern world have debated the meaning of Islam, and they have used religion and its linguistic referents in this exercise. It may be compared with the discourse of religious studies, also using similar terms (religion, religious, ritual, myth, etc.) to create an intellectual discipline. The study of religion has been subjected to critical review, while Islamic reform and modernism has generally been approached as an object to be studied and represented.

Religion became a constitutive term in the discourse, created and used by Muslim intellectuals since the $19^{\text {th }}$ century. They provided the framework and the means through which values and projects were conceptualized and then employed in dialogue, exchanges, and politics. 'Abduh turned to religion, its relation with reason, and its social value, to conceptualize a project of reform. This project was not a simple borrowing from the foundation texts of Islam, or earlier Muslim intellectuals, but included a reconceptualization of religion. This project was created in interaction with colonial interlocutors who wanted 
to show that Islam and Muslims were backward and worthy of colonization. 'Abduh took some of these ideas and inverted them for his project. This gesture was not a tactic made for a fleeting encounter, but the beginning of a discourse, a self-reflective exercise in setting up definitions and values ascribed to religion and the religious. Abu Zayd showed us this discourse at the end of the $20^{\text {th }}$ century, working with a refined definition of religion $(d \bar{i} n)$ as discourse that he developed from De Saussure. However, he did not follow a postmodernist trend, but a critical self-reflective stance that posited a distinction between $d \bar{i} n$ and $a l-f i k r$ al-dīn $\bar{\imath}$ (religion and religious thought). I have offered a hint of an intra-Muslim exchange in this discourse, particularly evident in Abū Zayd's discussion of Qasim Amin, Tahir al-Haddad, and Fazlur Rahman. Others have pointed to a critical exchange going on over the meaning, value, and function of religion over the course of the $20^{\text {th }}$ century (Tayob 2009; Senturk 2009; Dressler 2015).

It would appear that this discourse was a reflection of the Western intellectual hegemony that has dominated politics and the social sciences in general. This is the argument followed by Asad and others, and more widely in Dressler's and Mandair's edited work that documents how 'religionmaking' dominated state formation on a global scale. The collection of essays by Dressler and Mandair shows how a Western framework of religion was imposed and adopted by statesmen and intellectuals in non-Christian religions in North American, Europe, and Asia (Dressler \& Mandair 2011). Only one essay in this collection shows a resistance to this transformation, and that is the essay of Turner on how Buddhist monks resisted and rejected religion-making of the state (Turner 2011). It might appear that the distinction between the religious and secular has imposed itself on those working on the periphery in general, and on Muslim modern intellectuals in particular - a cursory knowledge of religious studies reveals the source of definitions and frameworks for religion used by these Muslim intellectuals. Terms like 'religion', 'essence', 'function', and 'discourse' might be traced to the founders of religious studies like Max Müller (1823-1900), Cornelius Tiele (1830-1902), Chantepie de la Saussay (1848-192), and Brede Kristensen (1867-1953), but there is no evident engagement with the Western discipline of religious studies. More importantly, the origins of the Western discipline as discussed in my review above, suggest that the earliest ideas of essence and function found in 'Abduh and others in the $19^{\text {th }}$ century were only beginning to emerge in the West. A strong case can be made that this new discourse may 


\section{Abdulkader Tayob}

be better thought of as a parallel or perhaps an intersecting development with the Western discourse of religious studies - with some distinct differences.

Muslim intellectuals have reformulated uses of $d \bar{i} n$ among premodern theologians and philosophers. There are no direct references that indicate a conscious and deliberate reworking from this history among the intellectuals that I have studied, but there is no doubt that a reference to din (religion) as an abstract category can easily be found among some of the major thinkers in the history of Islam. For example, Ibn Rushd (he died in 1198) wrote on the relationship between religion ( $\operatorname{din})$ and philosophy (Hourani 1976). Ibn Khaldun, the great historian, considered the function of religion that maintained a political order (Ibn Khaldun 1967). The mystic, Jalāl al-Dīn Rumi considered the various meanings of religion and faith in his famous prose work Fìh $\bar{\imath} m \bar{a}$ fih $\bar{\imath}$ (Rumi 1961). It may be argued that the intellectuals in the $19^{\text {th }}$ century were implicitly drawing on these resources. It was not an invention as Jonathan Smith has argued for religious studies, but a term that was at hand and reformulated for a new purpose.

The idea of tajdid offers a tempting name for this modern discourse. Before the $19^{\text {th }}$ century, tajdid was formulated around an expectation of a reformer (mujaddid) and an appeal to an uncontested earlier prophetic model (Sunnah). There is a prophetic hadith that predicted that a reformer (mujaddid) would appear at the end of every century to renew Islam (Moosa \& Tareen 2012; Tayob 2014). The modern discourse of religion that I am discussing has more or less dispensed with the idea of a reformer, and the value and form of the Sunnah has been exposed to intense debate (Lee 1997). The Muslim discourse of religion turns around the value, form, and relevance of revelation, seen essentially as texts. Texts are approached and studied through definitions and assumptions of what are called religion, religious, and the secular. What is distinctive of the $19^{\text {th }}$ century and then later the $20^{\text {th }}$ century intellectuals, is the central role played by religion as a term to define, to work with, and to assume in formulations of what the meaning of texts are. In the next few decades, religion has become more than an idea, it became a discourse. Like other discourses, these latter definitions are not impervious to borrowing from contemporary Western and non-Western ideas, but still, foundational texts of revelation mark the limits of the discourse.

The Islamic discourse is self-consciously religious, but there is no extensive discussion of a sacred presence or a sympathetic 'bracketing' of important beliefs and suppositions that one finds in the Western discourse of 
religious studies. The Islamic discourse is religious, but not engaged in 'theological' debates of the unseen, the sacred, or the reverential. There is no presence of a religion dissimulated in noumena, the essence of religion that must be assumed and bracketed, or patterns that the phenomena display. Much of the critical review of Eliade and other phenomenologists does not apply to this discourse. Rather than a theology or set of elusive patterns of spirit, the discourse is more clearly defined as politics. It is a politics of authenticity, identity, and moral values. It emerged at the height of colonial triumph, during a political era dominated by Europe and the West. There is some level of legitimation for the new modern state, as seen in the career of 'Abduh in the colonial state. However, the discourse occupies a marginal role in state policies and in popular politics. The case of Abū Zayd provides a good example of how it falls between an obvious legitimation of the state, and popular religion.

The discourse of Islamic modernism is not a cultural representation of the 'other', but a project of cultural, religious and political engagement, and renewal. It is not directed at the 'other' in whose image the self emerges triumphant or dejected under the critique of postmodernism and postcolonialism. It is a deeply engaged project of the self that is open for critical assessment and revision and is led by a demand for renewal rather than simply classification.

What are the postcolonial and decolonial implications of this discourse? It is rejected from many sides. Cast as Islamic modernism or simply modernist, it is accused of being too Western by many Muslims, or too religious for its Western detractors. In the politics of identity and representation that pervade the public sphere, it suffers greatly. It has failed to claim authenticity because it works with the past and the present, with the local and global, with the self and the 'other'. As I have shown, though, the modern discourse of religion by Muslim intellectuals over this period is testimony to an authenticity sustained over a long period of time. I have also shown that the discourse cannot be characterized as a pale reflection of a Western approach to religions. It has been innovative with regard to the terms drawn from the past and worked with terms that were either developed independently or in conversation with a broad Western humanistic and social scientific tradition. It is a creative project that merits more critical appreciation and engagement.

Finally, for the study of religions, this discourse helps to turn attention to how religion has been used as a critical discourse of society and history in a different tradition. It is a discourse that is not merely subject to representation, 


\section{Abdulkader Tayob}

but that stands alongside the dominant discourse of religious studies engaging in similar exercises. Recognizing the parochial nature of the Western discourse, it behooves scholars of religion to turn their attention to such discourses elsewhere. One need not only refine the existing hegemonic tradition, but to critically appreciate discourses of religion elsewhere. The essay has hopefully turned attention to one such discourse of religion among Muslim intellectuals.

\section{References}

'Abduh, M. 1368. Risālat Al-Tawhid. Cairo: Dār al-Manār.

'Abduh, M. 1989. Al-Islām, Dīn al-'ilm wa 'l-madaniyya. Beirut: Manshūrāt Dār Maktabat al-Hayāt.

Abū Zayd, N.H. 1988. al-Ta'wīl fì Kitāb Sībawayh. Alif: Journal of Comparative Poetics 8: 82-117.

Abū Zayd, N.H. 1993. al-Ittijāh al- 'aqlī fì 'l-tafsīr. Beirut: Dār al-tanwīr.

Abū Zayd, N.H. 1994. Naqd al-Khitab al-Dini. Cairo: Dar Sina.

Abū Zayd, N.H. 1996a. al-Imām al-Shāfi '̇̀ wa ta'sīs al-aydiyulūjiyyah alwasatiyyah. Cairo: Maktabah Madbūlī.

Abū Zayd, N.H. 1996b. Khițāb Ibn Rushd bayn ḥaqq al-ma rifah wa ḍughūt al-naqị̣̂. Alif: Journal of Comparative Poetics 16: 6-35.

Abū-Zayd, N.H. 1999. The sectarian and Renaissance discourse. Alif: Journal of Comparative Poetics (Gender and knowledge: Contribution of gender perspectives to intellectual formations) 19: 203-222.

Abū Zayd, N.H. 2000. The Qur'an: God and man in communication. Available at: http://www.let.leidenuniv.nl/forum/01_1/onderzoek/lecture.pdf. (Accessed on 12 July 2018.)

Abū Zayd, N.H. 2001. The Qur'anic concept of justice. Available at: http://them.polylog.org/3/fan-en.htm. (Accessed on 12 July 2018.)

Asad, T. 1986. The idea of an anthropology of Islam. Washington D.C.: Center for Contemporary Arab Studies, Georgetown University.

Asad, T. 1993. Genealogies of religion: Discipline and reasons of power in Christianity and Islam. Baltimore: John Hopkins University Press.

Asad, T. 2001a. Thinking about secularism and law in Egypt. Leiden: ISIM. 
Asad, T. 2001b. Reading a modern classic: W.C. Smith's the meaning and end of religion. History of Religions 40, 3: 205-222.

Bowen, J.R. 1987. Islamic transformations: From Sufi doctrine to ritual practice in Gayo culture. In Kipp, R.S. \& S. Rodgers (eds.): Indonesian religions in transition. Tucson: University of Arizona Press.

Bowen, J.R. 1989. Salat in Indonesia: The social meaning of an Islamic ritual. Man (N.S.) 24, 4: 600-619.

Bowen, J.R. 1993. Muslims through discourse: Religion and ritual in Gayo societies. Princeton: Princeton University Press.

Bowen, J.R. 2001. Shari 'a, state, and social norms in France and Indonesia. Leiden: ISIM.

Bowen, J.R. 2004. Beyond migration: Islam as a transnational public space. Journal of Ethnic and Migration Studies 30, 5: 879-894.

Capps, W.H. 1995. Religious studies: The making of a discipline. Minneapolis: Fortress Press.

Chidester, D. 1996. Savage systems: Colonialism and comparative religion in Southern Africa. Charlottesville: University Press of Virginia.

Chidester, D. 2004. 'Classify and conquer': Friedrich Max Müller, indigenous religious traditions, and imperial comparative religion. In Olupona, J. (ed): Beyond primitivism: Indigenous religious traditions and modernity. London, New York: Routledge.

Chidester, D. 2014. Empire of religion: Imperialism and comparative religion. Berkeley: University of Chicago Press.

Chidester, D. 2017. Beyond religious studies? The future of the study of religion in a multidisciplinary perspective. Nederlands Theologisch Tijdschrift 71, 1: 74-85.

Dressler, M. 2015. Rereading Ziya Gǒkalp: Secularism and reform of the Islamic state in the late Young Turk period. International Journal of Middle East Studies 47, 3: 511-531.

Dressler, M. \& A.-P.S. Mandair (eds.) 2011. Secularism and religion-making. Oxford, New York: Oxford University Press.

Dubuisson, D. \& W. Sayers 2003. The Western construction of religion: Myths, knowledge, and ideology. Baltimore: John Hopkins University Press.

El Guindi, F. 1981. Veiling infitah with Muslim ethic: Egypt's contemporary Islamic movement. Social Problems 28, 4: 465-485. 
Foucault, M. 1977. Nietzsche, genealogy, history. In Bouchard D.F. (ed.): Language, counter-memory, practice: Selected essays and interviews. Ithaca: Cornell University Press.

Grosfoguel, R. 2011. Decolonizing post-colonial studies and paradigms of political-economy: Transmodernity, decolonial thinking, and global coloniality. Transmodernity: Journal of Peripheral Cultural Production of the Luso-Hispanic World 1, 1:38 pages.

Haj, S. 2009. Reconfiguring Islamic tradition: Reform, rationality and modernity. Stanford: Stanford University Press.

Hirschkind, C. 1995. Heresy or hermeneutics? The case of Nasr Hamid Abu Zayd. Available at: https://web.stanford.edu/group/SHR/51/text/hirschkind.html. (Accessed on 2 August 2018.)

Hirschkind, C. 2001. Civic virtue and religious reason: An Islamic counterpublic. Cultural Anthropology 16, 1: 3-34.

Hirschkind, C. 2006. The ethical soundscape: Cassette sermons and Islamic counterpublics. New York: Columbia University Press.

Hoebink, M. 1998. Thinking about renewal in Islam: Towards a history of Islamic ideas on modernization and secularization. Arabica xlvi, 29-62.

Hourani, G.F. 1976. Averroes: On the harmony of religion and philosophy. Available at: http://www.muslimphilosophy.com/ir/fasl.htm. (Accessed on 21 May 2018).

Ibn Khaldun, A.A.-R.M. 1967. The muqaddimah: An introduction to history. London: Routledge \& Kegan Paul.

Kersten, C. 2011. Cosmopolitans and heretics: New Muslim intellectuals and the study of Islam. New York: Columbia University Press.

King, R. 1999. Orientalism and religion: Post-colonial theory, India and 'the Mystic East'. London: Routledge.

Kippenberg, H.G. 1983. Diskursive Relgionswissenschaft: Gedanken zu einer Religionswissenschaft, die weder auf einer allgemeinen gültigen Definition von Religion noch auf einer Überlegenheit von Wissenschaft basiert. In Gladigow, B. \& H.G. Kippenberg (eds.): Neue Ansätze in der Religionswissenschaft. Munich: Kösel-Verlag.

Kippenberg, H.G. 1994. Rivalry among scholars of religions: The crisis of historicism and the formation of paradigms in the history of religions. Historical Reflections 20, 3: 377-402.

Kippenberg, H.G. 2000. Religious history, displaced by modernity. Numen 47, 3: 221-243. 
Lee, R.D. 1997. Overcoming tradition and modernity: The search for Islamic authenticity. Boulder: Westview Press.

Macleod, A.E. 1991. Accommodating protest: Working women, the new veiling, and change in Cairo. New York: Columbia University Press.

Mahmood, S. 2005. Politics of piety: The Islamic revival and the feminist subject. Princeton: Princeton University Press.

Mahmood, S. 2006. Secularism, hermeneutics, and empire: The politics of Islamic reformation. Public Culture 18, 2: 323-247.

Masud, M.K. \& A. Salvatore 2009. Western scholars of Islam on the issue of modernity. In Masud, M.K., A. Salvatore \& M. van Bruinessen (eds.): Islam and modernity: Key issues and debates. Edinburgh: Edinburgh University Press.

McCutcheon, R.T. 1995. Review: The category 'religion' in recent publications: A critical survey. Numen 42, 3: 284-309.

McCutcheon, R.T. 1997. Manufacturing religion: The discourse on sui generis religion and the politics of nostalgia. Oxford: Oxford University Press.

Merriam-Webster Dictionary. 2018. Numen. Available at: https://www.merriam-webster.com/dictionary/numen. (Accessed on 10 August 2018.)

Mignolo, W.D. 2007. Delinking: The rhetoric of modernity, the logic of coloniality and the grammar of de-coloniality. Cultural studies 21, 2-3: 449-514.

Moaddel, M. 2001. Conditions of ideological production: The origins of Islamic modernism in India, Egypt, and Iran. Theory and Society 30, 5: 669-731.

Moaddel, M. \& K. Talattof (eds.) 2000. Contemporary debates in Islam: An anthology of modernist and fundamentalist thought. New York: Macmillan.

Moosa, E. \& S. Tareen 2012. Revival and reform. In Bowering, G. (ed.): The Princeton encyclopedia of Islamic political thought. Princeton: Princeton University Press.

Murphy, T. 2014. Representing religion: History, theory, crisis. London, New York: Routledge.

Nakata, N.M., V. Nakata, S. Keech \& R. Bolt 2012. Decolonial goals and pedagogies for indigenous studies. Decolonization: Indigeneity, Education and Society 1, 1: 120-140.

Rahman, F. 1979. Islam. Chicago: University of Chicago Press. 
Raschke, C. 2012. Postmodernism and the revolution in religious theory toward a semiotics of the event. Charlottesville, London: University of Virginia Press.

Rumi, J. 1961. Discourses of Rumi. London: J. Murray.

Salvatore, A. 1997. Islam and the political discourse of modernity. Reading: Ithaca Press.

Salwa, I. 2003. Rethinking Islamist politics: Culture, the state and Islamism. London: I.B. Tauris Publishers.

Schulze, R. 2000. A modern history of the Islamic world. London, New York: I.B. Tauris Publishers.

Senturk, R. 2009. Islamist reformist discourses and intellectuals in Turkey: Permanent religion with dynamic law. In Hunter, S.T. (ed): Reformist voices of Islam: Mediating Islam and modernity. New York: Routledge.

Smith, J.Z. 1978. Map is not territory: Studies in the history of religions. Leiden: Brill.

Smith, J.Z. 1980. The bare facts of ritual. History of Religions 20, 1/2: 112127.

Smith, J.Z. 1982. Imagining religion: From Babylon to Jonestown. Chicago: University of Chicago Press.

Smith, J.Z. 1998. Religion, religions, religious. In Taylor, M.C. (ed.): Critical terms for religious studies. Chicago: University of Chicago Press.

Smith, W.C. 1962. The meaning and end of religion. New York: New America Library.

Spivak, G.C. 2006. Can the Subaltern Speak? In Ashcroft, B., G. Griffiths \& $\mathrm{H}$. Tiffin (ed.): The post-colonial studies reader. London: Routledge.

Strenski, I. 2015. Understanding theories of religion: An introduction (thinking about religion). Malden, Oxford: Wiley-Blackwell.

Tayob, A. 2009. Religion in modern Islamic discourse. London: Hurst.

Tayob, A. 2014. Back to the roots, the origins and the beginning: Reflections on revival (Tajdīd) in Islamic discourse. Temenos: Nordic Journal of Comparative Religion 50, 2: 257-271.

Turner, A. 2011. Religion making and its failures: Turning monasteries into schools and Buddhism into a religion in colonial Burma. In Dressler, $\mathrm{M}$. \& A.-P.S. Mandair (eds.): Secularism and religion-making. New York: Oxford University Press.

Voll, J.O. 1982. Islam: Continuity and change in the modern world. Boulder: Westview Press. 
Voll, J.O. 1983. Renewal and reform in Islamic history: Tajdid and Islah. In Esposito, J.L. (ed.): Voices of resurgent Islam. New York: Oxford University Press.

Weismann, I. 2001. Taste of modernity: Sufism, Salafiyya, and Arabism in late Ottoman Damascus. Leiden: Brill.

Wiebe, D. 1991. Phenomenology of religion as religio-cultural quest: Gerardus van der Leeuw and the subversion of the scientific study of religion. In Kippenberg, H.G. \& B. Luchesi (eds.): Religionwissenschaft und Kulturkritik: Beiträge zur Konferenze 'the history of religions and critique of culture in the days of Gerardus van der Leeuw (1890-1950)'. Marburg: Diagonal-Verlag.

Wiebe, D. 1994a. From religious to social reality: The transformation of 'religion' in the academy. The notion of 'religion' in comparative research: Selected proceedings of the XVIth Congress of the International Association for the History of Religions, Rome, 3-8 September 1990. Rome: L'Erma di Bretschneider.

Wiebe, D. 1994b. Transcending religious language: Towards the recovery of an academic agenda. In Bianchi, U., F. Mora \& L. Bianchi (eds.): The notion of 'religion' in comparative research: Selected proceedings of the XVIth Congress of the International Association for the History of Religions, Rome, 3-8 September 1990. Rome: L'Erma di Bretschneider.

Abdulkader Tayob Religious Studies University of Cape Town Abdulkader.Tayob@uct.ac.za 